Apidologie, 1980, 11 (1), 47-55.

\title{
CHEMICAL ANALYSIS OF LOUISIANA POLLEN AND COLONY CONDITIONS DURING A YEAR
}

\author{
Norbert M. KAUFFELD \\ U.S. Department of Agriculture \\ Agricultural Research \\ Science and Education Administration \\ Carl Hayden Bee Research Center \\ 2000 East Allen Road \\ Tucson, Arizona 85719
}

\begin{abstract}
SUMMARY
Nineteen amino acids were present in pollen collected by honey bees, Apis mellifera L., in Louisiana throughout a year. Proline, lysine, glycine, and phenylalanine showed considerable variation throughout the year. The correlations for square centimeters of brood, volume of pollen collected, square centimeters of stored pollen, and amino acids present in the pollen were relatively high.
\end{abstract}

\section{INTRODUCTION}

Large quantities of pollen are fed to larvae of honey bees, Apis mellifera L., after they are 2 days old. Also, large quantities are consumed by young adults during the development of certain glands. TODD and BisHOP (1946) reported that an average colony of $45-50,000$ honey bees consumed ca. $45.5 \mathrm{~kg}$ of pollen/year.

AUCLAIR and JAMIESON (1948) analyzed pollen from dandelion, willow, and mixed pollen and reported that it contained alanine, $\beta$-alanine, a-amino-n-butyric acid, arginine, aspartic acid, cystine, glutamic acid, glutamine, glycine, histidine, hydroxy proline, isoleucine, leucine, lysine, methionine, proline, serine, threonine, tryptophan, tyrosine, and valine. The amounts varied with the plant sources. BIEBERDORF, et al. (1961) found the same amino acids in the pollens of 107 plants, but some contained only 4 of the amino acids and others contained 14 . Haydak (1937) found cystine, histidine, lysine, and tryptophan in the pollens he was testing against peanut, linseed, cottonseed, and soybean meals. Nielson et al. (1955) found 20 amino acids in the 
pollen from corn, alders, and pines. WEAvER and KuIKEN (1951) found 10 amino acids in the pollens from post oak, white larkspur, willow, bluebonnet and partridge pea and in some mixed pollens. Plainly, the number of amino acids present in pollens varies according to plant sources.

In nutrition studies, several of the amino acids have been tested for their effect on the growth of honey bee larvae and the metabolism of adults. BARKER and LEHNER (1972) found a slight decrease in proline in sugar fed bees after flight, therefore, it may be a minor source of flight energy. DE GROOT (1953) listed 10 amino acids as essential in a paper reporting his own research and a complete review of the literature dealing with the essential, non-essential, and other amino acids required for growth of honey bees; mosquitoes, Aedes; flies, Drosophila and Calliphora; cockroaches, Blattidae; carpet beetles, Anthrenus scrophulariadae (L.); rats; chicks; and man. However, 3 had stimulative value only, and 5 were non-essential for honey bee growth and metabolism. HAYDAK (1970) also reviewed honey bee nutrition.

The data regarding the square centimeters of brood reared, the honey, and pollen stored in the hive, and the amount (grams) of pollen gathered during the same year should enable other investigators to make preliminary comparisons that could lead to nutritional tests.

This is a report of the amino acids present in pollen collected in Louisiana during an entire year. The data collected was to be used as a basis for development of a nonpollen diet composed of natural materials which would have nutritional factors similar to pollen during peak periods of brood rearing.

\section{MATERIALS AND METHODS}

Sixteen colonies of bees on the Burden Plantation, 8 miles east of Baton Rouge, Louisiana were divided into 2 groups of 8 colonies each, and pollen traps were attached to each. Pollen was collected from the groups alternately so the colonies would be able to maintain their populations; this was necessary because of the great efficiency of the traps in removing pollen from the bees. A specially designed pollen trap (KAUFFELD, 1976) was used to collect the pollen. Twelve colonies were placed adjacent to each of the test groups. from which data were collected on the amount of brood reared and storage of honey and pollen.

During the year, all the pollen that was collected from one group of colonies every 3 days for 2 weeks was mixed into a composite sample and stored in a deep freezer at $-20^{\circ} \mathrm{C}$. Then, the 26 samples were packed in dry ice and sent to Ralston Purina Company, St. Louis, Missouri for biochemical analysis of the pollen for the 19 amino acids mentioned most frequently in the literature. All values presented were calculated on the basis of $\mathrm{g} / 100 \mathrm{~g}$ of sample of dry weight. Approximate analyses for moisture, protein, ash, fat and fiber were also run. Amino acid analysis was done on an acid hydrolysate using the Moore and Stein ion exchange technique. Tryptophan was analyzed separately by a colorimetric method. A brief list of some of the nectar and pollen plants from which bees collected the major amount of pollen during the brood rearing cycles is given. 


\section{RESULTS AND DISCUSSION}

Data presented in Figs. 1 and 2 indicate that less than $1 \mathrm{~g}$ per $100 \mathrm{~g}$ (dry wt.) of methionine $(+=$ essential), $\beta$-alamine $(-=$ non-essential), and hydroxyproline $(-)$ were present in the samples during the year. The amounts of tyrosine $(-)$, alanine $(-)$, trytophan $(+)$, threonine $(+)$, leucine $(+)$, valine $(+)$, isoleucine $(+)$, and histidine $(+)$, varied from a low of $2 \mathrm{~g}$ to about $8 \mathrm{~g} / 100 \mathrm{~g}$ (dry wt.) but individually were relatively uniform throughout the year (Figs 1 and 2).

Also, the amounts of phenylalanine (+), arginine $(+)$, proline $(-)$, and aspartic acid (-), varied the most throughout the year (Figs. 1 and 2).

Correlation coefficients for 27 variables were calculated (Table 1) and it is conceded that with that many variables, the significance of a few may not be as high as shown. However, it appeared necessary to consider them all in this initial analysis. Each one should be checked in feeding tests to determine its relative importance in the metabolism of the honey bee.

Correlation coefficients calculated for $\mathrm{cm}^{2}$ of brood $\times \mathrm{cm}^{2}$ stored pollen and $g$ pollen (collected by bees) gave highly significant values of $+0.623^{* * *}$ and $+0.499^{* * *}$ respectively (Table 1). Doull (1973) showed similar correlation coefficient values for the same parameters. Although all of the correlation coefficients in Table 1 are significant at the 5,1 and $0.1 \%$ levels, there are a few that need to be mentioned specifically. Methionine and histidine have significant correlation values of $+0.357^{*}$ and +0.318 * respectively for $\mathrm{cm}^{2}$ brood $\times$ amounts of each amino acid but in the correlation of $g$ pollen (collected) $\times$ amounts of each amino acid the values were not significant. Also, the correlation values for $\mathrm{cm}^{2}$ brood $\times$ amount glycine and $g$ pollen $x$ amount glycine were $-0.553^{* * *}$ and $-0.386^{* *}$, respectively. $\mathrm{Cm}^{2}$ brood $x$ amount serine had a negative correlation value of $-0.422 * *$ but a positive correlation value of $+0.622 * * *$ for $g$ pollen $\times$ amount serine.

Figure 3 shows a decrease in stored pollen and amount of pollen collected that coincided with the decrease in brood rearing during the period March 25 to April 20. However, a greater decrease in brood rearing occurred during the period May 3rd and June 1st. At the time the amount of stored pollen was relatively high and the amount of pollen collected had decreased from the peak collection about April 25. After the June 15 peak in brood rearing, the decrease of pollen collected coincided with the decrease in stored pollen and brood rearing. The increase in brood rearing that occurred during the period of August 24 to October 27 may have been a response to the amount of pollen collected and stored. Brood rearing steadily decreased from October 5 to November 15th and did not respond to the relatively large amount of pollen collected from October 5 th to November 30th. The percent of crude protein in the pollen increased to $3 \%$ during the period July 31 to September 25 (Fig. 4). Further research must be carried out to determine the relationship presented in these data 

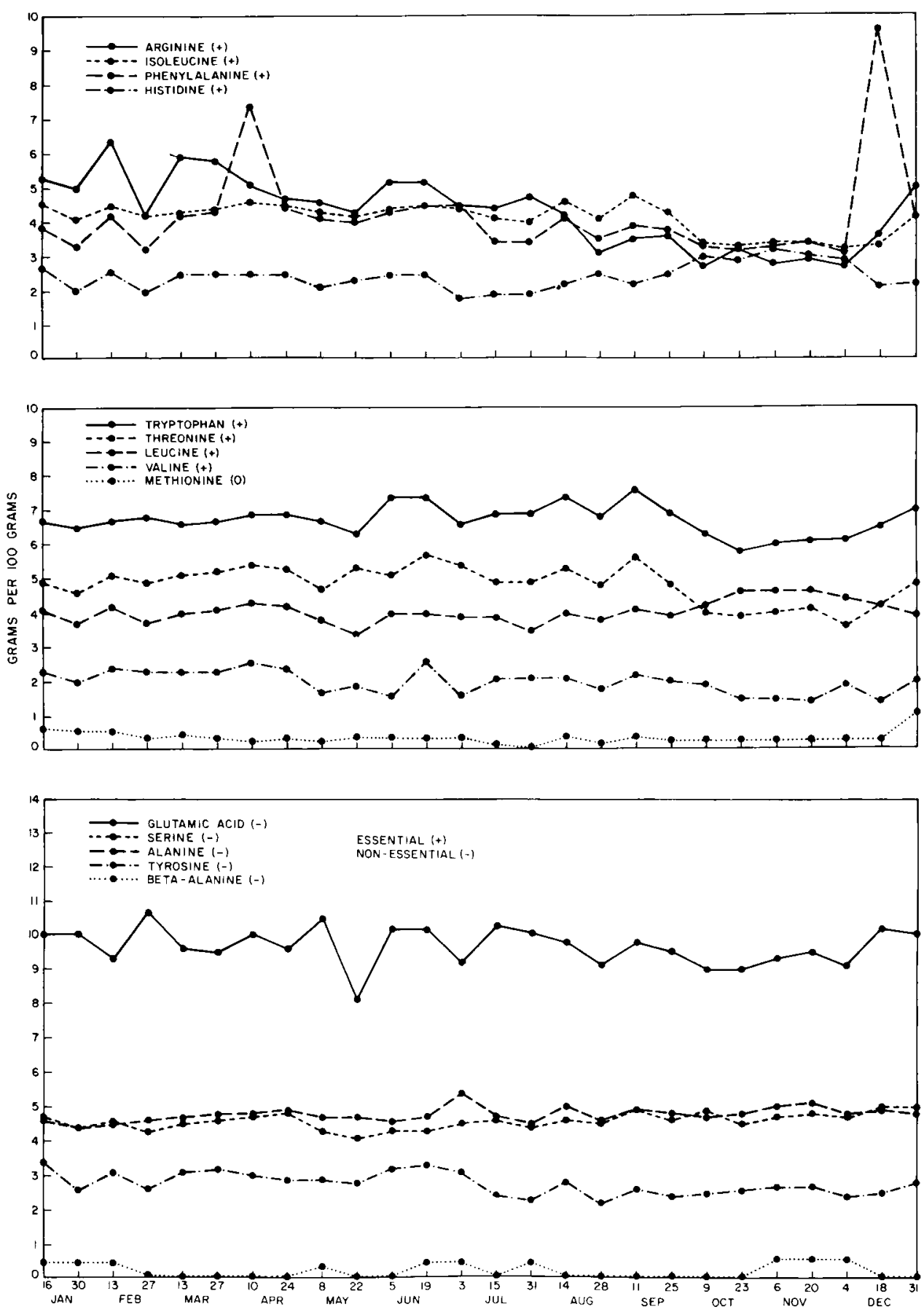

FIG. 1. - Amounts of amino acids present in composite pollen samples made up of 3-day collections made over 2-week periods. 


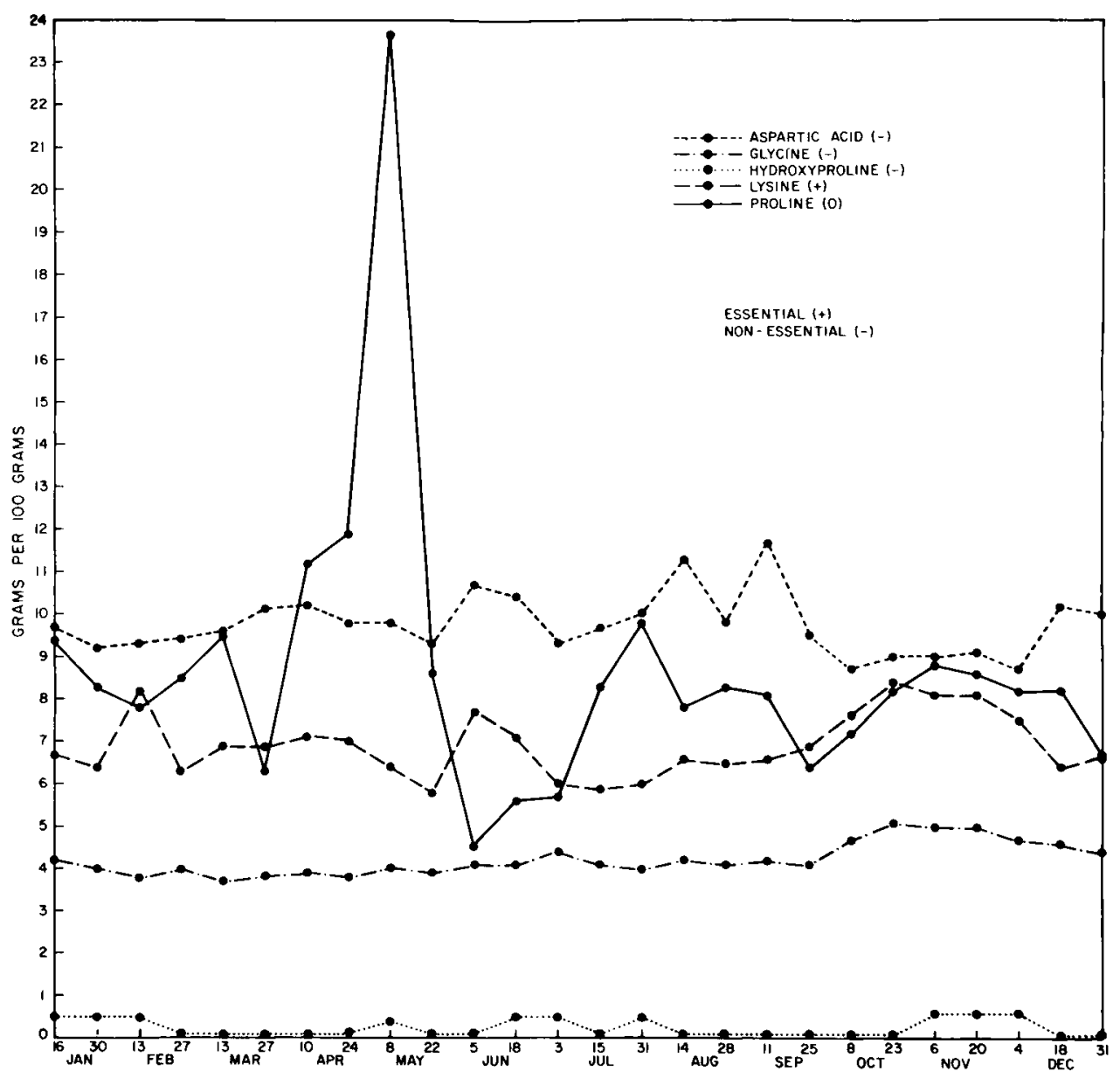

FIG. 2. - Amounts of amino acids present in composite pollen samples consisting of 3-day collections made over 2-week periods.

between the amounts of amino acids, $\mathrm{cm}^{2}$ of pollen (stored), $g$ pollens (amount) collected, and brood rearing.

The following plants were the principal sources of pollen but only a few of the total nectar and pollen plants blooming during the period of brood rearing from March 1 to March 31 (Fig. 3).

White Dutch clover (Trifolium repens), pear (Pyrus communis) L., chokecherry (Prunus melanocarpa) (A. Nels Rydb.), eastern redbud (Cercis canadensis) L., wax myrtle (Myrica), willow (Salix spp.), dewberry (Rubus spp.), Youpon (Ilex vomitoria) and ragwort (Senecio sp.). From the low point in brood rearing on April 6 to that of May 17 (Fig. 3), white Dutch clover (Trifolium repens), Persian clover (Trifolium resupinatum L.), willow (Salix sp.), blackberry (Rubus sp.), Youpon (Ilex vomitoria), 
TABL. 1. - Correlation-coefficient values for several amino acids in pollen for $\mathrm{cm}^{2}$ of brood, stored honey and pollen and amount ( $g$ ) of pollen collected.

\begin{tabular}{lc}
\hline \hline Criteria & Correlation \\
& Values \\
\hline $\mathrm{cm}^{2}$ of brood $\times \mathrm{cm}^{2}$ of pollen & $+.623^{* * *}$ \\
$\mathrm{~cm}^{2}$ of brood $\times \mathrm{g}$ of pollen & $+.499^{* * *}$ \\
$\mathrm{~cm}^{2}$ of brood $\times$ amt. of valine & $+.572^{* * *}$ \\
$\mathrm{~cm}^{2}$ of brood $\times$ amt. of isoleucine & $+.524^{* * *}$ \\
$\mathrm{~cm}^{2}$ of brood $\times$ amt. of arginine & $+.474^{* * *}$ \\
$\mathrm{~cm}^{2}$ of brood $\times$ amt. of leucine & $+.412^{* *}$ \\
$\mathrm{~cm}^{2}$ of brood $\times$ amt. of tyrosine & $+.389^{*}$ \\
$\mathrm{~cm}^{2}$ of brood $\times$ amt. of methionine & $+.357^{*}$ \\
$\mathrm{~cm}^{2}$ of brood $\times$ amt. of histidine & $+.318^{*}$ \\
$\mathrm{~cm}^{2}$ of brood $\times$ amt. of glycine & $-.553^{* * *}$ \\
$\mathrm{~cm}^{2}$ of brood $\times$ amt. of serine & $-.422^{* *}$ \\
$\mathrm{~cm}^{2}$ of honey $\times \mathrm{g}$ of pollen & $-.717^{* * *}$ \\
$\mathrm{~cm}{ }^{2}$ of honey $\times \mathrm{cm}{ }^{2}$ of pollen & $-.318^{*}$ \\
$\mathrm{~g}$ of pollen $\times$ amt. of serine & $+.620^{* * *}$ \\
$g$ of pollen $\times$ amt. of tyrosine & $+.502^{* * *}$ \\
$\mathrm{~g}$ of pollen $\times$ amt. of valine & $+.414^{* *}$ \\
$\mathrm{~g}$ of pollen $\times \mathrm{cm}$ of pollen & $+.363^{*}$ \\
$\mathrm{~g}$ of pollen $\times$ amt. of arginine & $+.343^{*}$ \\
$\mathrm{~g}$ of pollen $\times$ amt. of isoleucine & $+.307^{*}$ \\
$\mathrm{~g}$ of pollen $\times$ amt. of glycine & $-.386^{* *}$ \\
\hline$* * * * *$ Significant at 5,1, and $0.1 \%$ level. & \\
\hline \hline
\end{tabular}

ligustrum (Ligustrum sp.), poison ivy (Toxicodendron sp.), blue vervain (Verbena sp.), wild ligustrum (Ligustrum sp), and tree ligustrum (Ligustrum sp.), were the major sources of pollen. Similarly, from May 17 to the peak in brood rearing on June 15 (Fig. 3), bees collected the major amount of pollen from blue vervain (Verbena sp.), Johnsongrass (Sorghum halepense L. Pers.), dallisgrass (Paspalum dilatatum Poir), Chinese tallow-tree (Sapium sebiferum), sumac (Rhus sp.), pepper vine (Ampelopsis arborea (L. Rusby), and spiny pigweed (Chenopodium sp.).

After June 15, there was a relatively gradual decrease in brood rearing, volume of pollen collection and a storage of pollen (Fig. 3). The decrease continued until August 24th. Blue vervain (Verbena sp.), Johnsongrass (Sorghum halepense L. Pers.), sumac (Rhus sp.), pepper vine (Ampelopsis arborea L. Rusby), spiny pigweed (Chenopodium sp.), partridge pea (Chamacrista robusta Poll.), buttonbush (Cephalanthus occidentalis L.), boneset (Eupatorium sp.), giant ragweed (Ambrosia trifida L.), pink smartweed (Polygonum sp.), were the major sources of pollen during this period. From August 24 th to November 30th, honeybees collected most of their pollen supply from blue vervain (Verbena sp.), Johnsongrass (Sorghum halepense L. Pers.), partridge pea (Chamacrista robusta Poll.), boneset (Eupatorium sp.), pink smartweed (Polygonum sp.), giant ragweed (Ambrosia trifida L.), American crownbread (Verbesina sp.), Goldenrod (Solidago sp.), and small ragweed (Ambrosia sp.).

Received for publication in August 1979. 


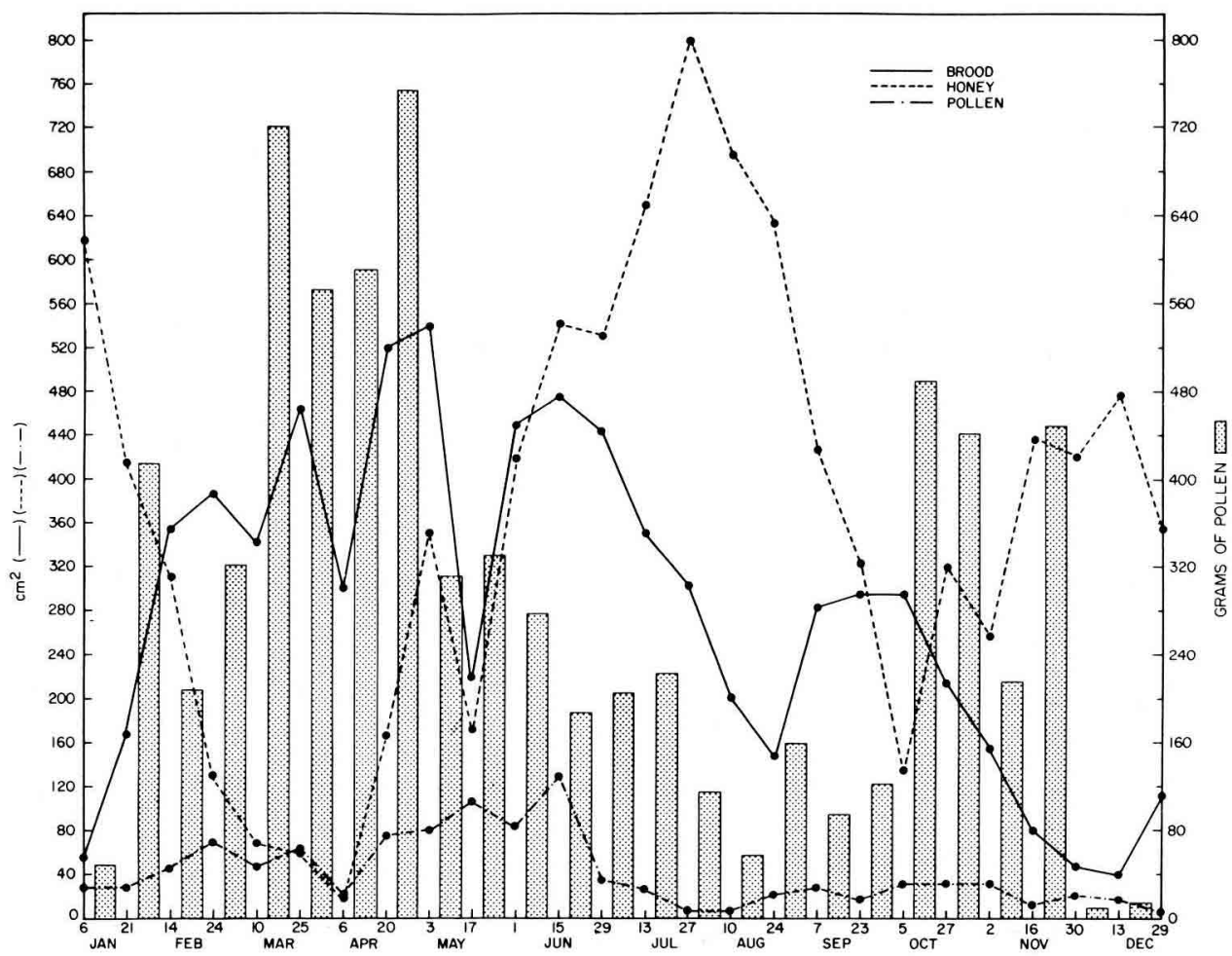

Fig. - 3. - Square centimeters of brood, stored pollen, and honey and grams of pollen collected.

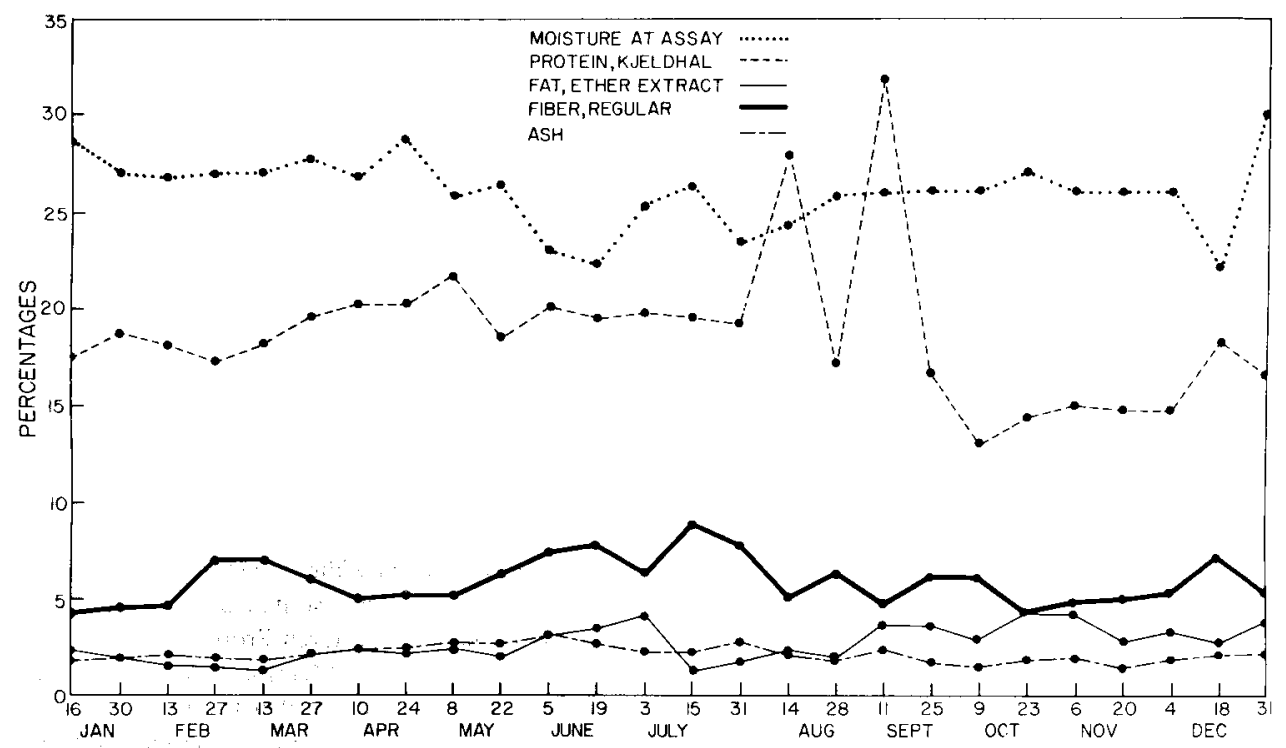

FiG. 4. - Proximate analysis of composite samples of pollen made up of 3-day collections made over 2week periods. 


\title{
ACKNOWLEDGMENTS
}

Grateful appreciation is extensed to AL RABY and DEAN BRISTER for their assistance in managing the colonies and collecting pollen samples. Appreciation is also extended to Dr. Gary Richardson for the statistical analysis of the data presented.

\section{RESUME \\ ANALYSE CHIMIQUE DU POLLEN DE LOUISIANE ET CONDITIONS DE LA COLONIE DURANT UNE ANNÉE}

On a analysé les acides aminés présents dans 26 échantillons de pollen récoltés chacun durant deux semaines au cours d'une année. Les résultats de l'analyse devaient être utilisés pour formuler un régime artificiel possédant les mêmes proportions en protéines et en acides aminés que le pollen. Dix-neuf acides aminés, tels que la méthionine ( $+=$ indispensable), la $\beta$-alanine $(-=$ non indispensable) et l'hydroproline étaient présents dans les échantillons tout au long de l'année. Les quantités de tyrosine $(-)$, leucine $(+)$, valine $(+)$, isoleucine $(+)$, histidine $(+)$ ont varié de $2 \mathrm{~g}$ à environ $8 \mathrm{~g} / 100 \mathrm{~g}$ de poids sec, mais prises individuellement furent relativement uniformes durant toute l'année.

Les plus fortes variations au cours de l'année ont été enregistrées pour les quantités de phénylalanine $(+)$, arginine $(+)$, proline $(-)$ et acide aspartique $(-)$. Du 27 mars au 8 mai la quantité de proline est montée jusqu'à $23,5 \mathrm{~g} / 100 \mathrm{~g}$ de pollen et s'est abaissée rapidement à $4,5 \mathrm{~g} / 100 \mathrm{~g}$ du 8 mai au 5 juin. Il est intéressant de noter que du 6 avril au 8 mai l'ẻlevage du couvain a atteint un maximum d'environ $530 \mathrm{~cm}^{2}$ mais a décru fortement jusqu'à environ $230 \mathrm{~cm}^{2}$ aux alentours du 17 mai. Les données ne montrent pas de pics et de creux similaires pour les quantités d'acide aminés et de couvain couvrant une période similaire de temps au cours de l'année.

Les coefficients de corrélation entre les acides aminés individuels et d'autres mesures (surface de couvain, surface de miel et de pollen stocké) ont montré des corrélations positives et négatives hautement significatives. Les valeurs du coefficient de corrélation entre la valine, l'isoleucine, l'arginine, la leucine, la tyrosine, la méthionine et l'histidine d'une part et l'élevage du couvain de l'autre étaient significativement positives aux seuils de probabilité de 5 à $0,1 \%$. La glycine et la sérine avaient des valeurs de corrélation négatives de $-0,533$ et $-0,422$ avec l'élevage du couvain. Il est pourtant nécessaire de faire des tests de nourrissement pour chacun des acides aminés pour établir les corrélations.

Il y a des valeurs significativement positives de corrélation entre les grammes de pollen d'une part et les quantités de sérine, tyrosine, valine, arginine et isoleucine d'autre part pour les seuils de probabilité de 5 à $0,1 \%$. Il y a pourtant une valeur significativement négative de corrélation au seuil de $1 \%$ de probabilité entre les grammes de pollen récoltés et la quantité de glycine dans le pollen

\section{ZUSAMMENFASSUNG}

\author{
CHEMISCHE ANALYSE VON POLLEN AUS LOUISIANA \\ UND DER ZUSTAND DER VÖLKER IM VERLAUFE DES JAHRES
}

Bei 26 Pollenproben, gesammelt in Perioden von jeweils zwei Wochen während eines ganzen Jahres, wurde der Gehalt an Aminosäuren untersucht. Die Ergebnisse der Analyse sollten dazu dienen, eine Formel für eine künstliche Diät zu finden, die ähnliche Protein- und Aminosäuren-Proportionen enthält, wie sie im Naturpollen zu finden sind. Die folgenden 19 Aminosäuren wie z.B. Methionin ( $+=$ essentiell), $\beta$-Alanin $(-=$ nicht essentiell) und Hydroxyprolin waren während des Jahres in den Proben vorhanden. Die Mengen von Tyrosin (-), Leucin (+), Valin (+), Isoleucin $(+)$ und Histidin $(+)$ variierten zwischen einer unteren Grenze von $2 \mathrm{~g}$ bis etwa $8 \mathrm{~g} / 100 \mathrm{~g}$ Trockengewicht, aber individuell blieben sie das Jahr über ziemlich konstant. 
Die Mengen von Phenylalanin (+), Arginin (+), Prolin (-) und Asparticsäure (-) variierten am stärksten im Jahresverlauf. Vom 27. März bis zum 8. Mai stieg die Prolinmenge zu einem Gipfel von 23,5 g in $100 \mathrm{~g}$ Pollen an, um dann scharf zwischen dem 8.Mai und dem 4,5 g/100 g abzusinken. Es ist interessant, dass die Brutfläche zwischen dem 6.April und 8.Mai auf einem Gipfel von $530 \mathrm{~cm}^{2}$ anstieg, um dann aber bis zum 17.5. deutlich auf $230 \mathrm{~cm}^{2}$ abzusinken. Sonst zeigen die Daten keine ähnlichen Gipfel und Tiefpunkte für den Gehalt an Aminosäuren und für die Bruttätigkeit während einer ähnlichen Periode im Jahresverlauf.

Die Korrelationskoeffizienten zwischen den einzelnen Aminosäuren und anderen Messdaten $\left(\mathrm{cm}^{2}\right.$ Brut, $\mathrm{cm}^{2}$ Honig- und Pollenvorrat) zeigten hochsignifikante positive und negative Korrelationen. Die Korrelationskoeffizienten für Valin, Isoleucin, Arginin, Leucin, Tyrosin, Methionin und Histidin $x$ Brutaufzucht waren signifikant positiv im Wahrscheinlichkeitsbereich von $5 \%$ bis $0,1 \%$. Glycin und Serin hatten negative Korrelationswerte von $-0,533^{* * *}$ bzw. von $-0,422^{* *}$ in Bezug auf die Brutmenge. Um die Bedeutung dieser Korrelationen zu beweisen, müssten aber noch Fütterungsversuche mit jeder dieser Aminosäuren durchgeführt werden.

Es bestehen signifikant positive Korrelationswerte für Gramm Pollen x Menge von Serin, Tyrosin, Valin, Arginin und Isoleucin auf dem $5 \%$ - bis zu dem $0,1 \%$ - Niveau der Wahrscheinlichkeit. Es wurde jedoch eine signifikant negative Korrelation mit $1 \%$ Wahrscheinlichkeitsniveau für Gramm gesammelten Pollen x der Menge von Glycin im Pollen gefunden.

\section{REFERENCES}

Auclair J. L., JAmieson C.A., 1948. - A qualitative analysis of amino acids in pollen collected by bees. Science, 108, 357-358.

Bieberdorf F. W., Gross A. L., Weichlen R., 1961. - Free amino acid content of pollen. Ann. Allergy, 19, 867-876.

De Groot A. P., 1953. - Protein and amino acid requirements of the honey bee (Apis mellifica L.). Physiol. Comp. Oecol., 3 (fasc. 2 \& 3), 90 pp.

Doull K., 1973. - Relationship between pollen, broodrearing and consumption of pollen supplements by honeybees. Apidologie, 4, 285-293.

HAYDAK M. M., 1937. - Further contribution to the study of pollen substitutes. J. Econ. Entomol., 30, 637-642.

Haydak M. H., 1970. - Honey bee nutrition. Annu. Rev. Entomol., 15, 143-156.

Kauffeld N. M., 1976. - Pollen trap with cleaning grid. U.S. Patent No., 3,995,338.

Nielson N., Grommer J., Lunden R., 1955. - Investigations on the chemical composition of pollen from some plants. Acta Chem. Scand., 9, 1100-1106.

ToDd F., BisHop R. K., 1946. - Trapping honey bee gathered pollen and factors affecting yields. J. Econ. Entomol., 33, 866-870.

Weaver N., Kuiken K., 1951. - Quantitative analysis of the essential amino acids of royal jelly and some pollens. Ibid., 44, 635-638. 